\title{
Greek and Indian Physiognomics
}

\author{
Zysk, Kenneth Gregory
}

Published in:

Journal of the American Oriental Society

DOI:

10.7817/jameroriesoci.138.2.0313

Publication date:

2018

Citation for published version (APA):

Zysk, K. G. (2018). Greek and Indian Physiognomics. Journal of the American Oriental Society, 138(2), 313-325. https://doi.org/10.7817/jameroriesoci.138.2.0313 


\title{
Greek and Indian Physiognomics
}

\author{
KENNETH ZYSK \\ UNIVERSITY OF COPENHAGEN
}

\begin{abstract}
The focus of this paper is the relationship between the Greek and Indian systems of physiognomics in antiquity. The study seeks to find similarities between the two geographically separated modes of thought and, as a result, to posit a plausible exchange of ideas about the human body as omen in antiquity, in which the flow of ideas went both ways between the Greek and Indian cultures in the ancient world.
\end{abstract}

This paper explores the relationship between Greek and Indian systems of knowledge concerning divination by means of the marks on the body of a human being, commonly called by its Greek-derived name, physiognomics or physiognomy. The investigation builds on my recent study of the Indian system of physiognomics, known in Sanskrit as 'the marks of men and women' (strīpurușalakșaṇāni). ${ }^{1}$

In particular, I should like to examine select Greek passages from the Physiognōmonika ${ }^{2}$ attributed to Aristotle (i.e., ps.-Aristotle after Swain) around 300 BCE. The work is divided into two parts, styled Tractates A and B. In addition, I shall occasionally refer to the Physiognomy of the Sophist Marcus Antonius Polemon, which is based largely on the ps.-Aristotle work and written in the mid-second century $\mathrm{CE}$, but preserved only in Arabic translations that survive in manuscripts from the late thirteenth century ${ }^{3}$ and in the Greek abridgement by the Sophist Adamantius sometime between the third and mid-fourth centuries. ${ }^{4}$ The information on Indian physiognomics comes from a Sanskrit version found in the earliest extant collection of the Indian astral sciences (Jyotiḩśāstra), known as the Gärgìyajyotișa (the astral sciences according to Garga), which reflects the system of physiognomics known and practiced in the northwestern and western parts of the Indian subcontinent at or before the first century BCE.

I shall address four specific points of similarity found in both the Greek and the Sanskrit sources: 1. the use of a common stock of technical anatomical terms; 2 . the use of a common toe-to-head orientation for examination of the marks on the body; 3. similarities (and differences) between the three earlier systems of physiognomics that inform ps.-Aristotle and the system of early Indian physiognomics; and 4. the common emphasis on the eyes.

Although the varying styles of the two presentations of the human physiognomics betray their different literary genres, a fundamental lexical similarity between them points to a common source of knowledge. The prose of the Greek fits the philosophical literature, while the

1. Zysk, Indian System, vol. 1: 40-48. The reader should consult this work for necessary references that may be missing in this paper.

2. Except in the chart of comparative anatomical terminology and in the original text citations found in the notes, Greek words, like those in Sanskrit, are given in their transliterated form.

3. Two Arabic manuscripts come from the Topkapi Sarayi Museum in Istanbul and make up the so-called TK recension. One is dated AH 680/ 1281 CE (Ahmet III 3207, fos. 33a-75a) and the other is undated (Ahmet III 3245, 65 fos.). One Arabic manuscript comes from the University Library in Leiden, called simply the Leiden recension. It dates from $\mathrm{AH} 757 / 1356 \mathrm{CE}$ (Or. 198, fos. $2^{\mathrm{b}}-50^{\mathrm{a}}$ ). It is considered the most complete version of Polemon. Although the manuscripts are late, it is likely that Polemon was translated first into Arabic between the eight and tenth century CE (cf. Swain, Seeing the Face, 5, 227, 235, 238, 311, and 465).

4. Ibid., 487. 
Sanskrit verses are appropriate to the versified textbooks or Śāstras of the Brahman priests, which served as the storehouses for Hindu religious practices and ethics. The former blurs the distinction between the protasis and the apodosis of the conditional sentence characteristic of ancient omen literature, while the latter maintains it in verse-form. Where they demonstrate shared information is first in the choice of a specific set of technical anatomical terminology, and secondly in the directional orientation for the examination of the human body.

\section{A COMMON TECHNICAL ANATOMICAL VOCABULARY}

Both treatises mention a cluster of anatomical terms that serve as the basic or principal Greek sources (genos) and Sanskrit marks (lakșana). Although the total numbers vary in the two texts, a majority of the technical terms are common to both, so that the ten sources from Physiognōmonika and the eight basic marks from the Gärgìyajyotisa likely shared a common source. We begin with the Greek list.

\section{The Ten Greek Bodily Sources}

In the Tractate A, ps.-Aristotle specifies the following ten bodily sources (genos) that serve as signs (sèmeion) of a man's character:

1. movement (kinēsis)

2. forms/gestures (schēma)

3. complexion (chrōma)

4. character ( $\bar{e}$ thos) expressed on the face (prosōpon)

5. growth of hairs (of the body and head) (trichōma) ${ }^{5}$

6. oiliness/smoothness of the skin (leiotēs)

7. voice $($ phōnē $)$

8. flesh/muscle (sarx)

9. limbs (meros)

10. bodily shape as a whole / shape of the whole body (ho typos holou tou sōmatos). ${ }^{6}$

An elaboration and explanation of this list follows in this Tractate, where the sources are discussed in a different order: complexion/skin (chrōs), hair, flesh, movement, voice, the forms and characteristic expressions that appear on the face (ta de schèmata kai ta èthe ta epiphainomena epi tōn prosōpōn ${ }^{7}$ ), and a comparison between men and women based on size, strength, and bodily limbs (akrōtêria tou sōmatos). The author concludes by affirming his preference for the face, movement, and form over the individual body parts. ${ }^{8}$ Complexion is discussed under the anatomical term of skin; oiliness or smoothness is a property of flesh; form, combined with character, is an aspect of the face; and limbs are mentioned under

5. For trichōma, there is no Latin translation. It is noticed that ms. L (codex Musei Britannici Harleianus 5635) omits this source in the list, which could account for its being missing in the Latin translation, which was based on L.

6. 806 $.26-34$ (corresponding to Foerster 7 [pp. 16.10-11]). The Greek text throughout is based on Bekker's edition, Aristoteles Graece:

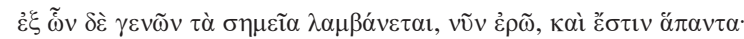

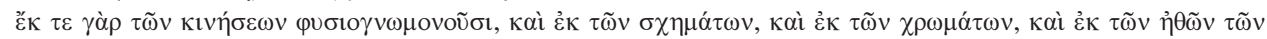

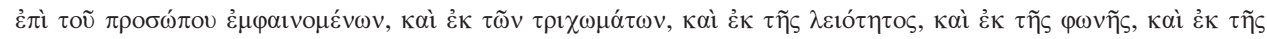

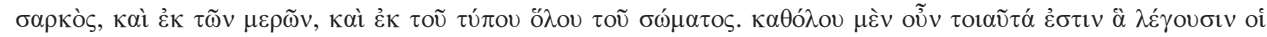

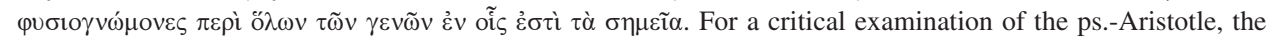
reader should consult Vogt, Physiognomonica.

7. The Latin reads: figurae autem et passiones quae apparent in facie.

8. $806^{\text {b }} .3-807^{\text {a }} .3$ (corresponding to Foerster 9-10 [pp. 18.7-22.9]). 
the discussion of gender-types. The difference in the two Greek versions of the enumeration arises from the author's method of explanation, where the order is changed and certain sources are grouped together, resulting in a particular Greek understanding of the ten basic sources.

The topic of the bodily sources serving as signs is addressed again in Tractate B at the end of the toe-to-head enumeration of the body parts, but the total number comes only to nine, ending with an overall praise of a medium-sized (metrios) body. This version of the sources contains material not previously mentioned in the list from Tractate A. Most noticeable is the use of opposites to characterize certain sources.

Following are the nine sources from Tractate B:

1. complexion includes a contrast between dark (melas) and light (leukos)

2. hairiness (dasys)

3. gait/bodily movement (bama)

4. hand gestures, i.e., bodily movements like those of the gait applied to the hand, forearm, and arm (peri de cheiros kai pēcheos kai brachionos phoras ai autai anatherontai)

5. eyes (ophthalmoi)

6. voice $(p h \bar{o} n \bar{e})$

7. stature, expressed in terms of small (mikros) and large (megas)

8. flesh (sarx) as either moist (hygros) or dry (xēros)

9. complexion (chrōma) as either warm (thermos) or cold (psychros). ${ }^{9}$

In addition to hand gestures, there is specified the bodily movement of gait, which includes walking and deportment in general as a separate category, whereas the tenfold list has only bodily movement. Moreover, the eyes replace the facial expression; stature in terms of small and large becomes both form and the body as a whole; and flesh and complexion are classified according to the opposite pairs of moist and dry and warm and cold respectively. These differences point to at least two versions of the basic bodily sources, one with ten and another with nine anatomical terms in a different configuration and with considerable elaboration. The specific mention of the eyes, rather than the gestures and characters expressed on the face, points to an emphasis on one anatomical part of the face, the eyes, that will become important in the literature on physiognomics beginning with Polemon's version of physiognomics (see below). A very similar set of sources, called marks (lakșana), occurs in the Sanskrit version of Garga's text.

\section{The Eight Basic Sanskrit Marks}

The Sanskrit text of Garga preserves a specific group of eight marks, which are used in omens to determine a man's character (sattva), which also figures as one of the eight:

1. bodily radiance, including natural glow (prabhā) and artificial oily sheen (sneha, snigdha)

2. scent (gandha)

3. character (sattva)

4. eyes (akși, netra, cakșus, drșți, ìkșaṇa)

5. body movement or gait (gati)

6. voice (svara, sarasvatī) 
7. size and form (pramāna, samsthāna)

8. complexion (varna $)^{10}$

\section{Greek and Sanskrit Technical Terminology}

When we compare this list to the tenfold version in Tractate A, there are seven direct matches: gati-kinēsis, svara-phōnēe, sattva-ēthos, varna-chrōma, saṃsthāna-schèma, pramāna-ho typos holou tou sōmatos, and sneha/snigdha-leiotēs. However, rather than considering character as an aspect of the face, the Sanskrit version understands it to be revealed by various marks or combination of marks, the most predominant being the eyes. The remaining three marks from the Greek list find direct matches from among other marks given

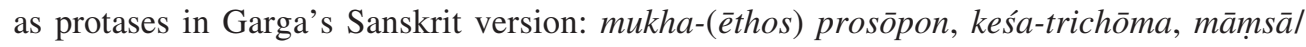
$m \bar{a} s \bar{a}$-sarx, and gâtra-meros. (See the chart below, where those marked in bold are direct matches between the two lists.) Eyes (akși, etc.), as part of facial expression, occur in the same semantic field as face in Tractate A, but they only find a direct match in the ninefold list found in Tractate B. Therefore, the match akși-ophthalmoi may be listed as among the important marks shared by Garga and the ps.-Aristotelian treatise.

In the ps.-Aristotelian discussion of the ten sources, chrōs (skin) finds a correspondent in Garga's tvac 'skin', yielding the match: tvac-chrōs. The Greek definition of stature in terms of mikros (small) and megas (large) is paralleled by Garga's dichotomy sthüla-krśa 'largethin'. ${ }^{11}$ Moreover, the Greek preference for medium size (metrios) mentioned at the end of Tractate B fits well Garga's text, where extremes are avoided. Such an idea involving a middle course could well have been influenced by early Buddhist doctrine. ${ }^{12}$

Two of the principal marks from Garga and Aristotle, svara-phōne (voice) and varnachrōma (complexion) also figure among the first three signs that indicate imminent death in early Indian medicine (Āyurveda), revealing physiognomics's connection with medicine in the Indian tradition. Only two of the basic marks from Garga do not find a Greek match: scent ( gandha) and bodily radiance in terms of the body's natural glow (prabha $).{ }^{13}$ Both are indicators of character (sattva) in Garga, confirming that the Sanskrit version understands sattva in a wider context than the ps.-Aristotelian treatise does èthos. Moreover, these terms also figure in the list of marks that can reveal impending death in the Indian medical tradition. The divinatory use of Sanskrit gandha and prabha is absent in all the Greek versions. Therefore, it is likely that both scent and natural bodily glow were unique marks in the early Indian versions of both physiognomics and the signs of imminent death in early Indian medicine. ${ }^{14}$

The analysis of Garga's list of eight basic marks and the ps.-Aristotelian list of ten and nine bodily sources in the two Tractates points to a rather close similarity in the choice and use of specialized medical terminology. The sheer number of coincidences suggests that the similarities are not accidental. Indeed, it points to a common choice of technical terms shared by the ancient Greek and the early Indian systems of physiognomics. Further, the Indian tradition has links to the early Indian medical tradition of Āyurveda. It is, therefore, not surprising that the physiognomics of the Aristotelian tradition finds similar modes of expression in the ancient Greek medical theories of the humors, which posit a relationship between a man's

10. See Garga 1.29-34 at Zysk, Indian System, vol. 1: 230-31; see also vol. 1: 59-60, vol. 2: 490-92, 533-34.

11. Garga 1.86 at Zysk, Indian System, vol. 1: 238-39; see also vol. 2: 509, 546.

12. See Zysk, Indian System, vol. 1: 44-45.

13. Ibid., 8-20.

14. Ibid., 45. 
physical appearance and his character and temperament via the four basic humors: blood, black bile, yellow bile, and phlegm. ${ }^{15}$ Moreover, the dichotomies in Tractate B point to an early medical orientation based on the concept of opposites, such as that found in ancient China. Therefore, a connection between physiognomics and medicine in the Greek tradition could reach back to Hippocrates (c. 460-370 BCE) and perhaps even China. The recognition that both Indian and Greek systems of physiognomics contain aspects of their respective medical traditions might also not be completely accidental. It could well reflect an exchange of technical information which is found in both Greek and Sanskrit early treatises on physiognomics.

The Basic Sources and Marks of Greek and Indian Physiognomics ${ }^{16}$

\begin{tabular}{|c|c|c|c|}
\hline Greek & Latin $^{16}$ & Sanskrit & English \\
\hline 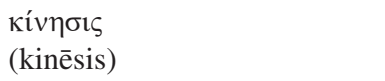 & motus & gati & movement \\
\hline $\begin{array}{l}\sigma \chi \tilde{\eta} \mu \alpha \\
(\text { schēma) }\end{array}$ & figura & samsthāna & form/figure/gesture \\
\hline $\begin{array}{l}\chi \rho \tilde{\omega} \mu \alpha \\
\text { (chrōma) }\end{array}$ & color & varṇa & complexion \\
\hline 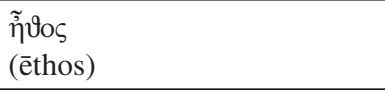 & $\operatorname{mos}$ & sattva & character \\
\hline $\begin{array}{l}\tau \rho i ́ \chi \omega \mu \alpha \\
\text { (trichōma) }\end{array}$ & & keśa/loman & hairs (of the head \& body) \\
\hline $\begin{array}{l}\lambda \varepsilon \text { có } \eta_{\zeta} \\
\text { (leiotēs) }\end{array}$ & levitas & sneha & (oily) smooth skin \\
\hline $\begin{array}{l}\varphi \omega v \eta ́ \\
\text { (phōnēē) }\end{array}$ & vox & \begin{tabular}{|l} 
svara \\
(sarasvatī)
\end{tabular} & $\begin{array}{l}\text { voice } \\
\text { (eloquence) }\end{array}$ \\
\hline $\begin{array}{l}\sigma \alpha ́ \rho \xi \\
(\operatorname{sarx})\end{array}$ & caro & māsā/māṃsā & flesh/muscle \\
\hline $\begin{array}{l}\mu \varepsilon ́ \rho \circ \varsigma \\
\text { (meros) }\end{array}$ & pars & $\begin{array}{l}\text { gātra } \\
\text { caraṇa, pāṇi, etc. }\end{array}$ & $\begin{array}{l}\text { limbs } \\
\text { feet, hands, etc. }\end{array}$ \\
\hline 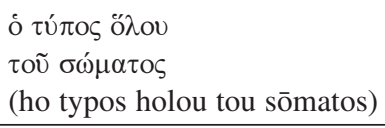 & $\begin{array}{l}\text { figura totius } \\
\text { corporis }\end{array}$ & $\begin{array}{l}\text { pramāṇa } \\
\text { dīrgha-hrasva } \\
\text { sthūla-krśa }\end{array}$ & $\begin{array}{l}\text { body measure } \\
\text { tall-short } \\
\text { wide-narrow }\end{array}$ \\
\hline
\end{tabular}

\section{THE TOE-TO-HEAD ORIENTATION FOR EXAMINATION OF THE BODY}

Another similarity between early Greek and Indian physiognomics occurs in their respective modes for enumerating the different parts of the human body. Both systems employ a technique with an orientation that begins at the feet and moves up systematically to the top of the head. It would appear that this too cannot be mere coincidence. The correspondence in their approaches offers an opportunity to explore a possible intrusion of an Indian mode of thought in an ancient Greek treatise attributed to Aristotle.

15. See Swain, Seeing the Face, 15-16, and cf. Popović, Reading the Human Body, 93-94, where he cites a small work of the physician Galen in which Aristotelian physiognomics is combined with the theory of humors.

16. The Latin is based on Bartholomaeo de Messana's thirteenth-century Latin rendering the Physiognonomika, in which he clearly delineates Tractates A and B. The Latin text accompanies Foerster's edition and corresponding Latin terminology is here added for the sake of completeness. 
Before the discussion of the nine sources in Tractate B, the ps.-Aristotelian text systematically goes through the body from the feet to the head, explaining how each part reveals something of the individual's character. This mode of thinking is distinctively different from the character revealed on the face. It represents an expanded view of what reveals character beyond the face and eyes in Tractate A. The orientation is maintained in Polemon (midsecond century CE) and Adamantius (third to mid-fourth century CE), where there is a slight modification so that the enumeration begins with both the feet and arms, i.e., the extremities. ${ }^{17}$ After Polemon/Adamantius, the approach is reversed to a head-to-toe system, known in Latin as a capite ad calcem in Greco-Roman physiognomics. It was first noticed in the Akkadian texts from Mesopotamian cuneiform tablets and later adopted in the Aristotelian book on animal anatomy (see below) and Greek traditions of medicine and rhetoric. It is most probably under the influence of these Greek sources that the Anonymous Latinus in his rewriting of Polemon between the mid-third and end of the fourth century CE obtained and applied the top-down orientation to physiognomics. From that point forward, the preferred method of physiognomic examination was head-to-toe. ${ }^{18}$ Because the head-to-toe orientation appeared both before and in the Aristotelian corpus and then again a little while later, the toe-to-head version of the Physiognommonika suggests an incursion into an already well-established and indigenous methodology that might well look back to Mesopotamian physiognomics for its origin. ${ }^{19}$

In Indian physiognomics, on the other hand, the toe-to-head orientation is the preferred method of inspection, being first seen in the women's marks (strīlakṣanāni) in Garga and fixed as the norm for both genders from Varāhamihira's Bṛhatsaṃhitā (sixth century CE). It too represents the indigenous orientation of the Indians.

The fact that the toe-to-head technique is found only in the earliest Greek physiognomic treatises points to an unprecedented change in Greek anatomical and physiognomic thought. Some may argue that the shift to toe-to-head was insignificant, resulting simply from the whim of the author. Such a fundamental directional orientation is far from capricious, however; the way one instinctively directs one's gaze is deeply ingrained in one's behavior, being passed on from one generation to the next. The instinctive way one turns one's head before crossing the street serves as a fitting example. In North America and Europe one is taught always to turn and look to the left, but in India and the United Kingdom it is reversed. The two modes of behavior are not interchangeable. If the one is to replace the other, a new way to direct one's glance would have to be learned from childhood over many generations to become the preferred mode. The instability of the toe-to-head orientation in early Greek physiognomics further indicates that it was not an instinctive form of behavior, learned over many generations; rather it appears to be an anomaly in the literature, come from somewhere else.

One could also argue that the toe-to-head orientation derived from examination of animals, most of which do not stand upright like humans. However, in the first part of his History of Animals, Aristotle uses the human body as a paradigm for the division of the parts of the body in the animal kingdom. He divides the body into five parts from the top down: head, neck, thorax, two arms, and two legs, and proceeds to describe each part in detail beginning

17. See Swain, Seeing the Face, 179, 317, 330, and Gleason, Making Men, 32. Interestingly, the top-down method is found in the TK recension of Polemon but not the Leiden text, and is the standard in the later Arabic treatises of firāsa (physiognomics), which follows the Islamic-Galenic medical tradition (Swain, Seeing the Face, 317).

18. Anonymous Latinus' Book of Physiognomy relies on three sources: a lost book of Loxus, ps.-Aristotle, and, principally, Polemon and survives in fifteen manuscripts from the twelfth to the fifteenth century (Swain, Seeing the Face, 179, 550-52).

19. Zysk, Indian System, vol. 1: 28-31, 46 n. 167. 
with the head. ${ }^{20}$ This further confirms that the head-to-toe orientation towards the body was the norm in the rest of Aristotle's corpus, dating from the fourth century BCE.

A similar change in the method of orientation during bodily examination is not found in the Indian physiognomic tradition. In fact, sources indicate that it was a natural development from a custom deeply rooted in the culture of South Asia. ${ }^{21}$

The toe-to-head system dominates the principal transmissions and versions of physiognomics found in India. Perhaps the earliest form of it is noticed in the enumeration of thirtytwo major marks of the Buddha, which is a familiar topic of doctrinal discussions in the Buddhist canonical literature both in Mahāyāna Buddhism, composed in Sanskrit, and in Theravāda Buddhism, composed in Pāli, whose canonical literature was composed before 29 BCE, when it was first written down in Śrī Lankā. The Sanskrit versions of the Buddhist canon, however, date from a century or two before the Common Era, which the Pāli scholar, K. R. Norman, believes to be the more precise time for the Pāli list of the Buddha's marks as well. ${ }^{22}$ It was the period when the Buddhist texts were undergoing a transition from Pāli to Sanskrit. This would place the earliest Buddhist formulation of the thirty-two marks in Pâli at just before the Common Era. This dating would then make the Buddhist versions of the marks of the Buddha roughly contemporaneous with, if not a little earlier than, the description of female marks recorded in the Gärgiyajyotisa. The fact that the method is the same, but the gender and marks are different, points to a commonality in method but a variation in usage.

The division of ps.-Aristotle's work into two tractates has an interesting correspondence in the Indian tradition. Tractate A concentrates on the ten basic sources and their elaboration, which corresponds to Garga's system of the man's eight basic marks. Tractate B, however, gives another version of the basic sources, where the eyes are featured and character is missing. On the other hand, it offers a systematic enumeration of the marks of the entire body from toe-to-head, which is paradigmatic in the Sanskrit sources. The bottom-up orientation would, therefore, appear to be traceable to the Indian tradition of physiognomics.

The justification for its South Asian origin lies rather in custom and folklore than in specialized literature. The instinctual reflex of keeping the eyes lowered in humility is indigenous to the culture and religion of the peoples of South Asia, where it is normal for individuals to greet their betters by prostrating themselves before them and touching their feet as a sign of respect and reverence. ${ }^{23}$ It is part of the early tradition of honoring the footprints of

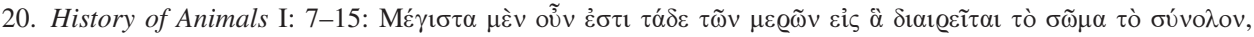

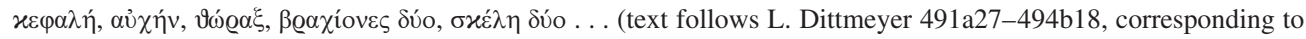
Bekker, vol. 4, 13-17). See also Thompson, Historia Animalium, 491 ${ }^{\mathrm{a}}-497^{\mathrm{b}}$. This translation, minus the text-critical notes, is found in Barnes, Complete Works of Aristotle, vol. 1, 782-91; cf. also Cresswell, Aristotle's History of Animals, 13-17.

21. I have come across only two examples where the presentations of the protases begin with the head: one in two Sanskrit versions of the thirty-two marks of the Buddha the other in one of the only treatises on Indian physiognomics in Tamil (Zysk, Indian System, vol. 1: 116, 170).

22. See Norman, Pāli Literature, 36 and 42. The same list occurs in two places in the Dīghanikāya: the Lakkhanasuttanta (DN 3, 142-179) and the Mahāpadānasuttanta (DN 2, 16-19), and once in the Majjhimanikāya: the Brahmāyusutta (MN 2, 136-137).

23. An exhaustive study of the function of feet in Indian culture is found in Bollée, "Folklore on the Foot." See especially sections A.5.1 on observing betters from toe-to-head and A.5.2.2 on prostrating oneself before betters and touching their feet. Cf. esp. (p. 32) Bṛhatkathāślokasamgraha (BKŚS) 24, 38: “. . persons deserving respect are looked at from the feet upwards because the looker lies prostrate before him; conversely the higher person observes others from top to toe" (sa-gomukham apaśyan mām ā śiraś caranam). 
the Buddha ${ }^{24}$ and has been a common practice for paying homage to deities and worthy persons still observed in modern-day India. In the more recent Indian physiognomic tradition, it is the principal method for the physiognomic inspection of a potential bride and her family. ${ }^{25}$

It is clear that the method and its procedure are based on behavior well ingrained in Indian life and culture, while in ancient Greece it was a technique very possibly introduced into the literature from among the basic tenets of Indian physiognomics. Therefore, the evidence thus far marshalled would rather strongly suggest that Tractate B of the ps.-Aristotle's Physiognōmonika could well derive in part from material that was shared mutually between the Indian and Greek physiognomic traditions, even though chronologically the Greek version appears to be older than any of the extant Indian brahmanic transmissions. Only the formulations preserved in the two Buddhist canons could date from the same period as the earliest Greek texts down to Polemon. The Buddhist version, however, does not mention the group of basic marks, suggesting that the Buddhist tradition preserved a form structurally linked to the Greek Tractate B, while the Hindu Sanskrit tradition of the astral sciences, first compiled by Garga, maintained a version with similarities to both Tractate A and B.

\section{SUMMARY OF POINTS 1 AND 2}

We have thus far pointed to two important similarities between early Greek and Sanskrit physiognomic literature:

1. the enumeration of the basic anatomical sources or marks

2. the toe-to-head orientation used in the examination of the body.

The first found in the Gärgìyajyotișa's section on the marks of men corresponds principally to Tractate A of the Physiognomonika. The second occurs throughout Indian physiognomic literature from Garga onward and in Tractate B of the Physiognomonika and Polemon's Physiognomy. Finally, both Indian and Greek systems of physiognomics share a common storehouse of knowledge with their respective medical traditions, a feature that they have in common with Mesopotamian physiognomics.

We now turn our attention to the third point of similarity between Indian and Greek physiognomics, which has not been addressed in my recent study. It occurs at the beginning of ps.-Aristotle's treatise in the discussion of the three known traditions of physiognomics.

\section{THE THREE KNOWN SOURCES IN PS.-ARISTOTLE'S PHYSIOGNŌMONIKA AND THE GĀRGIYYAJYOTISTA}

The next step in the exploration of similarities between early Greek and Indian physiognomic knowledge is the comparison of the three earlier methods of physiognomics (progegenēmenoi physiognommones kata treis tropous) mentioned in the Physiognōmonika with possible counterparts in Garga's chapter on human physiognomics.

According to the ps.-Aristotelian treatise, the three known systems of physiognomics are described as follows: ${ }^{26}$

24. See Burnouf, Le Lotus de la bonne loi, 553-647, and more recently Quaglotti, Buddhapadas, 1-78, with a catalogue of the Buddhapadas from India and Pakistan, the earliest of which might date from the first century BCE.

25. Bhaviṣya Purāna 1.28.3-7, which has a parallel in Buddhist literature. See Zysk, Indian System, vol. 1: 420-21; vol. 2: 807.

26. 805a.18-31 (corresponding to Foerster, 2 [pp. 6.10-8.8]):

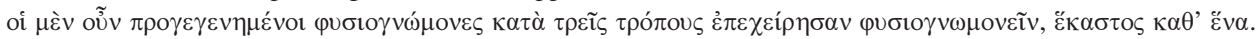

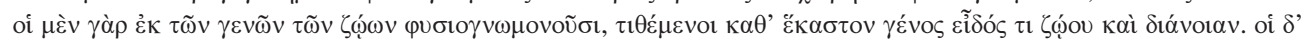


1. The method based on the genera of animals ( $e$ tôn genōn tōn zōōn), whereby there is correspondence between man and animal in both form (eidos) and thought (dianoia), so that if there is resemblance in body (soma), there is also resemblance in mind (psychē).

2. A comparable method that is not based on the similarities with the different kinds of animals, but with other kinds of human beings (ex autou tou tōn anthrōpōn genous), who are distinguished by ethnicity (ethnēe, such as Egyptian, Thracian, and Scythian, which relies on their appearances (opseis) and characters $(\bar{e} t h \bar{e})$. In the same way, the choices of the marks (tên eklogèn tōn sēmeiōn) of character derive from these ethnic types.

3. The final method derived from characters ( $\bar{e} t h \bar{o} n)$ that appear on the (face) (epiphainonemōn), where each character agrees with a mental state (diathesei), such as anger, fear, sexual arousal, and other emotions.

The text continues with a reasoned critique of these earlier systems, followed by the presentation of the Greek system of physiognomics. Each of the three will be discussed in relation to the contents of Garga's version.

\section{Animal Similes}

The use of animal similes abounds in Garga as it does in the earlier Mesopotamian omens, so that the technique is common to the three ancient systems of physiognomics. In the Greek treatise the emphasis is on land animals, such as the lion and leopard, which characterize respectively men and women. In the Mesopotamian and Indian traditions, similes of water-birds predominate, yet in India there is mention of terrestrial animals, such as lion and elephant, which exemplify members of the princely orders. In this regard, there is a closer similarity between the Indian and Mesopotamian traditions than between Indian and Greek physiognomics. ${ }^{27}$

\section{Ethnicity}

Physiognomics by means of ethnicity is particular to the Greek text, where specific ethnic peoples are mentioned: Egyptian, Thracian, and Scythian. In the version from the Gärgìyajyotișa ethnicity does not occur as a separate category of physiognomics. However, if one considers the whole of the section of the men's marks in Garga, one might view it as describing the auspicious type of man according to a Greco-Roman ideal, where the variations from the norm imply races of inauspicious natives, who populated northwestern and western India. Their anatomical features are presented, but their specific ethnic identity is wanting, perhaps because it was not known at the time. The method of ethnicity, as described in the Greek text, likewise, finds only tangential similarity to the Indian physiognomics compiled by Garga.

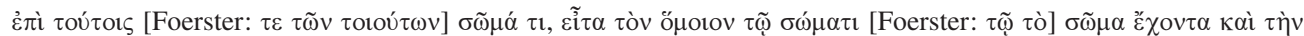

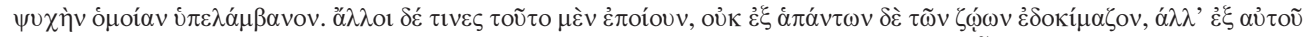

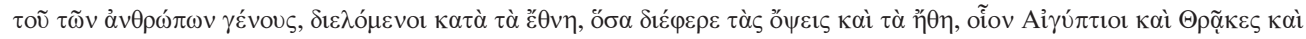

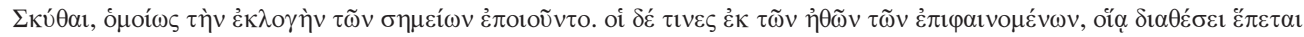

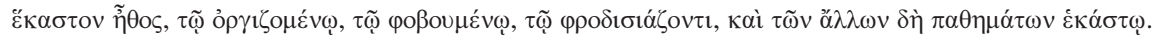

A version of this is found in the Anonymous Latinus's Book of Physiognomy (Swain, Seeing the Face, 551, 560-61).

27. See Zysk, Indian System, vol. 1: 35, 42, 233, 237, 241, 247, 255, and passim.
} 


\section{The Face}

Divination by means of the character, especially the eyes, is an important feature of Garga's description of the marks of men and points to an important similarity between the Greek and Indic physiognomic traditions. Although the Greek exposition in Tractate A mentions the whole face as the means for determining character, the version of Tractate B and the subsequent treatise of Polemon clearly understand the most important feature of the face to be the eyes. Likewise in Garga, there are no less than forty-two verses devoted to the man's eyes, which supply the principal protasis in the last half of the section on his marks of men. ${ }^{28}$

\section{EMPHASIS ON THE EYES}

The fourth and final point to be taken up in this discussion of the similarities between Greek and Indian physiognomics is the focus placed on the eyes, first mentioned in Tractate B of the Physiognomonika. It then became central to Polemon's Physiognomics and retained an important place in the works of Adamantius and the Anonymus Latinus (fourth century $\mathrm{CE}$ ). Garga's devoting such a large part of his discussion of the male marks to the eyes corresponds to Polemon's emphasis on eyes, for only the eyes can reveal the true character that lies within. The terminology and mode of expression in the following extracts differ slightly, mainly because of the literary conventions governing verse and prose, but there is an intrinsic similarity in the way the eyes are given preference in all versions:

Garga: “And, surely, expect the quality of man's eyes to be the best indicator (of his character)." 29

Polemon (Leiden): "Know that the eyes are the gateway to the heart, from which arise the cares of the soul and appear the secrets of the conscience." 30

"Of the physiognomical knowledge of the eye and the superiority of clear understanding of it over other bodily organs." 31

Adamantius: "But many of the signs and the sum of them is located in the eyes, and the soul appears through these as if through gates." 32

And finally from Anonymus Latinus: "The most significant signs are judged to belong to the eyes. They [i.e., the ancient physiognomists] want these to be seen as gates of the soulfor they say that the soul even shines out through the eyes and that this is the only avenue by which the mind can be approached and looked into." 33

While Garga employs the man's eyes to reveal his character (sattva), which corresonds to ps.-Aristotle's èthos, Polemon uses them to divulge his soul or mind (psychēe), which the Anonymus Latinus calls animus. Both ps.-Aristotle in Tractate B and Garga maintain the

28. Garga 1.19, 22, 27-28, 34, 48-54, 59-69, 71-75 at Zysk, Indian System, vol. 1: 248-49, 254-55, 256-59; vol. 2: 531-33, 534, 538-44.

29. Garga 1.63ab: etad eva tu śreștham ca netraih syāl lakṣaṇaṃ n⿳̣̂nām, lit, "Indeed, that best mark of men should be by the eyes."

30. Polemon (Leiden), Introduction: the eyes (Swain, Seeing the Face, 341; see 340 for Arabic text).

31. Polemon (Leiden), A5 (Swain, 341; Arabic 340), which the translator, Robert Hoyland, suggests might be part of the title (341 n. 11)

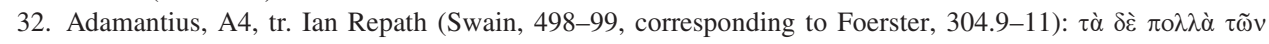

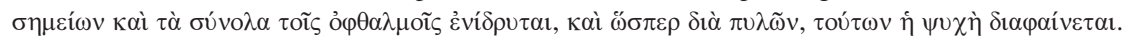

33. Anonymus Latinus 10 (Swain, 562-63]: potissima autem

signa iudicabuntur oculorum. hos enim tanquam fores animae videri volunt:

nam et animam dicunt per oculos emicare et solum hunc aditum esse, per quem

animus adiri atque introspici possit ... 
same basic idea that the eyes reveal a man's character, but only Garga and Polemon indicate a preference for the eyes. A revealing similarity between Garga and Polemon is their common use of the unusual animal simile of crab's eyes as a sign of inauspiciousness. ${ }^{34}$ However, only Polemon shifts from their revealing men's character to being windows to their souls, a concept followed in subsequent versions in Greek and Latin. Here Garga agrees with Polemon in emphasizing the eyes, but maintains the view that they reveal character (sattva), which is similar to ps. Aristotle's view in Tractate B. The coincidence between Garga and the Greek texts on the eyes is revealing of a common mode of thinking, including an unique use of animal similes. One might even speculate that since the verses devoted to the eyes occur as a single unit in the latter part of Garga's text, they represent a type of codified set of verses brought into Garga's collection. It cannot be determined who may have borrowed from whom, but it is clear that both the Greek and the Sanskrit versions shared a common emphasis on the eyes.

\section{CONCLUSION}

What more now can we ascertain about the relationship between Indian and Greek physiognomics from this analysis? First, three methods of physiognomics were known to exist at the time of ps.-Aristotle's Physiognōmonika, a treatise on Greek physiognomics made up of two treatises, each of which has a similarity to the Sanskrit physiognomic treatises. Secondly, of the three, only the first, animal similes, and the third, the face, are expounded in the Sanskrit Gārgīyajyotișa. Moreover, the predominance of similes to water-birds ties it closer to Mesopotamian than to Greek physiognomics. Only, the third method which focuses on facial expressions, especially of the character revealed by the eyes, finds correspondence in both Garga and the early Greek physiognomics of the Physiognomonika and of the later version composed by the Sophist Polemon and other authors. This similarity reveals that certain information was shared by both systems of ancient physiognomics.

An up-to-date study of Polemon's Physiognomics and its place in the physiognomic traditions of the Hellenistic and Arabic worlds is Simon Swain's edited volume, Seeing the Face, Seeing the Soul. Through a series of introductory essays followed by texts and translations, the story of Greco-Roman and early Islamic physiognomics is revealed, with a particular emphasis on the rich Sophist, Polemon, from Roman Smyrna in Asia Minor.

Even though Polemon's original Greek text is lost, what is known from the Arabic translations and Greek abridgement reveals little in common with Garga outside its focus on the eyes and use of a toe-to-head orientation for examining the body. The manner in which the eyes are treated varies in each treatise, and their literary styles are quite different. Garga's text is in verse with a metre of eight syllables per line. Polemon's text on the other hand reflects the prose style of Greek rhetoric with long and detailed descriptions. ${ }^{35}$ Whereas a part of Garga's version and all of Polemon use the eyes to read a man's character, ${ }^{36}$ another part of Garga uses a group of marks to foretell a man's future as well as his character. When all is taken into account, therefore, Garga embraces thought common to both the version of ps.-Aristotle and Polemon, but does not represent either in its entirety. Unlike the visual

34. Only the Arabic versions of Poleman mention the crab by name. The Greek and Latin summaries only give the description and character traits. Of these, the color red is shared by all versions of Poleman and Garga, and both consider the man inauspicious. In Poleman the crab-eyed man is mentally, physically, and verbally unstable. In Garga he is fond of dice, and two words are used for crab, kulira and karkața (Zysk, Indian System, vol 1: 232-33, 304-5; 40; vol 2: 539, 690, 798; Swain, Seeing the Face, 179, 205, 375, 385, 389, 516-17, and 576-78).

35. In fact, the metrical style of Garga resembles more the short prose of the Akkadian cuneiform physiognomic omens than the Greek and Roman didactic prose physiognomic treatises.

36. Swain, Seeing the Face, 125, 487; cf. 178-79; and Zysk, Indian System, vol. 1: 14, 37-38. 
orientation of the body, where Indian influence is apparent, the direction and flow of these ideas is difficult to determine. It rather points to a case of mutual exchange over time.

As we begin to explore the literature of science in ancient India and ancient Greece, similarities in thinking become ever more apparent to the point that we can begin to think in terms of a shared technical anatomical vocabulary, a common orientation in the examination of the body, and mutual focus on the eyes. It becomes increasingly less likely that these correspondences were merely coincidental. Early contacts between India and the Hellenistic world known from the sources in both Greek and Latin resulted in intellectual exchanges traceable in Sanskrit scientific literature. The above study has allowed us to see how the information might have been transferred from one intellectual tradition to another. One might, therefore, be tempted to posit the possibility of a common source for both Greek and Indian physiognomy, which is now lost; however, it might simply have been a case of the cross-fertilization of ideas. If, indeed, the latter, the results of such an intellectual encounter were significant enough to be preserved in the earliest literature on physiognomy in each culture. Mutual exchange then renders futile the search for a lost text or texts that informed both traditions. In a general way, however, we can begin to piece together a probable scenario for how such exchange of knowledge might have taken place.

We do not know precisely with whom and where these intellectual encounters could have taken place, but a likely place to begin the search might well be the meetings between the Indians and the Yonas or Yavanas. The recent work by the Finnish Indologist, Klaus Karttunen, clearly demonstrates that the Prākrit yona and the Sanskrit yavana referred first to the Greek-speaking invaders by land in the northwest of India in the early fourth century BCE and then again to the Hellenistic traders who came by sea beginning in the early centuries CE. ${ }^{37}$ Their presence in India is testified to in a variety of literature composed in both Sanskrit and Prākrit, but they are particularly known as scholars and astrologers in the scientific literature of Jyotihśāstra. It seems entirely plausible that from the time of Garga, a fruitful exchange took place between the Yona/Yavana scholars and diviners and their Indian counterparts, likely in the northwestern and western parts of the Indian subcontinent. Although the literary sources that might have facilitated this exchange are not extant, the bits and pieces that can be put together from the surviving texts indicate that aspects of Greek science found their way into early Sanskrit astrological works composed in western India, such as the Yavanajātaka of Sphujidhvaja after the first century CE and the Vrddhayavanajātaka of Mīnarāja in the fourth century. ${ }^{38}$ To this we can now add the chapter on the human marks from the Gärgìyajyotișa, whose final compilation dates from about the same time as Sphujidvaja. Importantly, the encounter with the Yonas/Yavanas could as well have resulted in the incorporation of aspects of the Indian physiognomic system into the emerging Greek literary tradition of physiognomy. Further details in this interesting story await the results from studies of the Gärgìyajyotișa currently undertaken by a small group of engaged scholars, whose efforts, it is hoped, will be enriched by the work of others interested in intellectual exchanges and developments in antiquity.

37. Karttunen, Yonas and Yavanas, esp. 368-75.

38. Ibid, 368-75. See also several works of Pingree: Jyotihśāstra, 81-83; Vṛddhayavanajātaka of Mīnarāja; Yavanajātaka of Sphujidhvaja. An especially good place to begin is the last six chapters of Mīnarāja's text, which deal with omens, including the sounds of crows and gestures of cuckoos, dogs, and cows. The first is found in Garga, and the latter, dealing with gestures (ceștita) of different animals, recalls Nātyaśāstra 22.100-145, which deals with the character (sattva) or behaviour (síla) of women. See Mak, "Date and Nature," and Zysk, Indian System, vol. 1: $25-26$. 


\section{ABBREVIATIONS}

DN Dīghanikāya (from the Buddhist Pāli Canon)

Garga Gārgīyajyotișa

MN Majjhimanikāya (from the Buddhist Pāli Canon)

\section{BIBLIOGRAPHY}

Aristoteles Graece ex. rec. Immanuelis Bekkeri. Edidit Academia Regia Borussica. Tomus IV et Tomus VI. Oconii: e Typographeo Academico, 1837.

Aristotelis de Animalibus Historia. Textum recognovit. Leonardus Dittmeyer. Lipsiae: in aedibus B.G. Teubneri, 1907.

Barnes, Jonathan, ed. The Complete Works of Aristotle. The Revised Oxford Translation, vol. 1. Bollingen Series, vol. LXXI.2. Princeton: Princeton Univ. Press, 1984.

Bollée, Willem. "Folklore on the Foot in Pre-modern India." Indologica Taurinensia 32 (2008): 39-145.

Burnouf, M. E. Le Lotus de la bonne loi, traduit du Sanscrit, accompagné d'un commentaire et de vingt et un mémoires relatifs au Buddhisme. Nouvelle édition avec un Préface de Sylvain Lévi. Vol. II: Appendice (Mémoires annexes). Biblothéque Orientale, vol. X. Paris: Librairie Orientale et Américaine, 1952.

Cresswell, Richard, tr. Aristotle's History of Animals in Ten Books. London: George Bell and Sons, 1883.

Foerster, Richardus, recensuit. Scriptores Physiognomonici. Graeci et Latini. Vol. 1. Lipsiae: Aedibus B.G. Teubneri, 1893.

Gleason, M. W. Making Men: Sophists and Self-Presentation in Ancient Rome. Princeton: Princeton Univ. Press, 1995.

Karttunen, Klaus. Yonas and Yavanas in Indian Literature. Studia Orientalia, vol. 116. Helsinki: Finnish Oriental Society, 2015.

Mak, Bill. "The Date and Nature of Sphujidvaja's Yavanajātaka Reconsidered." History of Science in South Asia 1 (2013): 1-20.

Norman, K. R. Pāli Literature: Including the Canonical Literature in Prakrit and Sanskrit of all the Hīnayāna Schools of Buddhism. A History of Indian Literature, vol. VII.2. Wiesbaden: Otto Harrassowitz, 1983.

Pingree, David. Jyotiḩsástra: Astral and Mathematical Literature. A History of Indian Literature, vol. VI.4. Wiesbaden: Otto Harrassowitz, 1981.

, ed. Vrrddhayavanajātaka of Minnarāja, 2 vols. Gaekwad's Oriental Series, vols. 162, 163. Baroda: Oriental Institute, 1976.

, ed. and tr. The Yavanajātaka of Sphujidhvaja. 2 vols. Harvard Oriental Series, vol. 48. Cambridge, Mass.: Harvard Univ. Press, 1978.

Popović, Mladen. Reading the Human Body: Physiognomics and Astrology in the Dead Sea Scrolls and Hellenistic-Early Roman Period Judaism. Leiden: E. J. Brill, 2007.

Quagliotti, Anna Maria. Buddhapadas: An Essay on the Representations of the Footprints of the Buddha with a Descriptive Catalogue of the Indian Specimens from the 2nd Century B.C. to the 4th Century A.D. Kamakura: Institute of Silk Road Studies, 1998.

Swain, S., ed. Seeing the Face, Seeing the Soul: Polemon's Physiognomy from Classical Antiquity to Medieval Islam. Oxford: Oxford Univ. Press, 2007.

Thompson, D'Arcy Wentworth, tr. Historia Animalium. The Works of Aristotle, vol. 4. Oxford: Clarendon Press. 1910. [Rpt. 1949]

Vogt, Sabrine, tr. and comm. Physiognomonica. Aristoteles, vol. 18: Opuscula, pt. 6. Berlin: Academy Verlag, 1999.

Zysk, Kenneth G. The Indian System of Human Marks. 2 vols. Sir Henry Welcome Asian Series, vol. 15. Leiden: E. J. Brill, 2016. 
